（6）血管内での造影剤の希䣋の問題

(7) その他

当セクションは，演題84〜91まで全て血流量測定に関 する演題であった。

演題84は，血流量測定の誤差要因について，ファント 么実験に基づく検討であった。

演題85は，血管の狭容の程度を時間濃度曲線を解析し て，定齿的に評価しようとする試みであった。今後の研 究課題として，画像上から狭容率を测定する方法が定量 性が高いのか，あるいは時間濃度曲線から解析する方法 が定童性が高いのか，上較検討をお願いしたい。

演題86は，血流量測定の問題点についての報告であっ た. DSA 像を用いて血流解析する場合， artifactの少な い画像であることが前提条件であり，撮影 technique が 重要なポイントになることは当然のことである。

演題87・89は，脳血流について， diffuseな面での血流 解析についての報告であうた. diffuse な面での血流解析 は，核医学的手法との精度比較が重要なポイントとなる と思われるので，患者に対する侵擎等を加味した上で， DSA の血流解析の意義等について,今後検討を加えてい ただきたい。

演題88は，核医学的な血流解析法の一つとして報告さ れている, relative perfusion efficiencyをDSAに適用 したものであった。この方法は，次に示すような欠点を 有するため，適応例について十分注意する必要があると 思われる。（1）時間濃度曲線の面積を比較する場合，同 一の血流量であっても，血流速度が異なれば，血流量と の相関が失われる。(2) 解析の対象部位として，正常例 においては，左右の血流の出現時間あるいは peak 時が 同一であることが前提条件となる。(3) peak 時間を検 出することは，ボーラス性あるいは拍動性等を考慮する と，困難なことが多い。

演題90は, DSA 像の定量的な血流解析法として, 位相解 析法ならびに mached filter 法の提案であった。両手法 とも，単に，2 個所関心領域を設定し，それの parameter 差を平均通過時間としているわけではなく， originality の高い方法である. mached filter 法は, hardware 化が 可能であることから，高速処理が期待できる。しかし， 現時点では，真の通過時間と mached filter 法から求め た通過時間との linearityについて若千問題点があり，今 後の研究成果に期待したい, mached filter 処理を motion artifact の除去方法として用いた場合には，十分 期待できる万法である。

演題91は，同時 2 万向肺動脈シネ像についての血流解
析の試みであった. originalityとしては，肺動脈の血管 径を計測する場合， 3 次元構造解析の手法を用いている こと，通過時間測定法として，時間濃度曲線分割法によ る相互相関関数 parameter を用いることである. 3 次元 的広がりをもつ血管を 3 次元構造解析し, 幾何学的に血 管径を計測する方法は理にかなった方法である。しかし， 処理時間等を考えた場合，3次元処理が一般ルーチン化 されるかどうかは疑問が残る，時間襄度曲線分割法につ いては，対象血管が肺動脈あるいは，造影剂を逆行性に 注入したIA DSA 等については，時間濃度曲線が 2 峰 性， 3 峰性等になることから，测定法としての一つの方 向となろう。

睤問 宝塚市立病院横野から，演題84～91の全演者に 対する質問として，ROIの大きさによって血流量が異な るのではないか？

答 平均血流量の概念からすれば，血管全体を囲む必 要がある。

\section{治療一1 照射技術一1}

座長 石山 忍（京都市立病院）

\section{2、テレコバルト低線量率治療の一考察}

横浜市立大学医学部病院中央放射線部放射線治療室

○寺廻信明・仙台真紀夫・井出正敏 佐々木健二・氏家盛通

シールド法によるテレコバルト低線量率治療（病巣線 量 $2 \mathrm{~Gy} ， 2 \sim 2.5 \mathrm{cGy} / \mathrm{min})$ では，長時間照射に伴いコリ メータからの漏れ線量が問題となるが，照射口全体のシ ールドにより改善させることができる、シールドの材質 は鉛を基準とし，銅・アルミ・アクリルの各組み合わせ による実験結果では鉛単独でのシールドがよいので当院 ではシールドの自重によるへッドの軸モーメントの影響 も考慮に入れ，照射口全体に直接鉛板（径 $16 \times 16 \mathrm{~cm}$ ：枚 数增隇により可変厚）を固定させる照射ロフィルタ，照 射口径より大型の鉛板（径 $33 \times 20 \mathrm{~cm}: 3.25 \mathrm{~cm}$ 厚）を固 定した三脚フィルタの組み合わせにより対策を行ってい る。

\section{3. 低線量率外照射法とその技術的問題}

九州大学医学部附属病院放射線部

○西村弘幸・泉 隆
城戸五郎・楪 秀糧扵

当院では低線量率外照射による放射線治療を行ってい る。この方法は，正常組織の障害が著しく減少し，合併 症も少なくなる、コバルト60照射装置を使用し，鉛フィ ルタにより $2 \mathrm{~Gy} / \mathrm{hr}$ に設定している。鉛フイルタとアク 